\title{
Revision of the Genus Christensenia
}

\author{
CRISTINA ROLLERI \\ Laboratory of Botany, Museo de La Plata, Paseo del Bosque, 1900 La Plata, Argentina
}

The present revision of Christensenia is the first for this genus. Observations of external and interna!foliar morphology, with particular emphasis on valid taxonomic characters of pinna indument and epidermis and soral paraphyses have shown that the taxa of the genus are C. aesculifolia Blume subsp. aesculifolia and subsp. korthalsii (de Vriese) Rolleri and C. lobbiana (de Vriese) Rolleri. Synangium outline, number of sporangia per synangium, and spore morphology are not systematically important. The morphology and physiology of adult porocyclocytic stomates and the presence, chemical composition, and density of microprojections of the mesophyll cell walls are adaptive and vary according to ambient humidity.

The generic name Christensenia was proposed by Maxon (1905) to replace the later homonym Kaulfussia Blume. De Vriese and Harting (1853) recognized four species of Kaulfussia, K. aesculifolia Blume (Java and the Philippines), K. assamica Griff. (Assam), K. korthalsii de Vriese (Sumatra and the Philippines), and K. lobbiana de Vriese (Java). Baker (1874, p. 444) synonymized the three later species in K. aesculifolia, and most later scholars agreed, including Maxon (1905), although he did acknowledge variation within the inclusive species C. aesculifolia (Blume) Maxon. Christ (1907) described C. cumingiana from the Philippines. Christensen (1938, p. 528) mentioned "2 Malayan species" without naming them. Copeland (1909) recognized C. aesculifolia, distributed from Malaysia to northern India, and C. cumingiana, from the Philippines. Later, Copeland (1958, pp. 27-28) reduced the latter species to C. aesculifolia and stated for it a general distribution from India to the Philippines, including Sumatra and Java. A similar concept was adopted by Holttu m (1955, pp. 45-46). Ching (1940) separated Christensenia from the Marattiaceae into a new family Christenseniaceae and recognized two species, C. aesculifolia and C. cumingiana, to which he later (Ching, 1959, p. 65) added C. assamica (Griff.) Ching. Pichi Sermolli (1970, p. 234) adopted Ching's segregation of the Christenseniaceae. Braithwaite (1977), Walker (1979), Hill and Camus (1986), and Camus (1990, p. 177-178) analyzed different aspects of the genus, but considered it to be monospecific.

\section{MATERIALS AND ME1110DS}

Specimens were examined from the Muséum National d'Histoire Naturelle, Paris (P), the Instituto Darwinion, San Isidro (SI), and the United States National Herbarium, Washington (US). Sorne 50-80 microscope slides were made of fragments from each taxon and are deposited at the Museo de La Plata.

Adult pinnae were cleared for $24 \mathrm{hr}$. with aqueous $2.5 \% \mathrm{NaOH}$ and saturated aqueous chloral hydrate. To minimize fragility of the samples after they were cleared, they were treated with a mixture of $540 \mathrm{ml} \mathrm{95 \%} \mathrm{ethanol,} 210 \mathrm{ml}$ distilled water, $240 \mathrm{ml}$ glycerine, and a few drops of formalin, which gave them elasticity and new strength. Staining material after this treatment gave better results.

General stains used were ferric chloride-tannic acid (Foster, 1934), Chlorazol Black E (Gurr, 1966, p. 275), Safranin-Aniline Blue (Gurr, 1966, p. 306), and 1\% aqueous Ruthenium Red. Several authors (Johansen, 1940, p. 200; Venning, 1934, p. 20, and 
D'Ambrogio de Argüeso, 1986, p. 76) used different concentrations of Ruthenium Red; I found that $1 \%$ is adequate and fast-acting (20-30 sec.).

Specific stains used to reveal the nature of epidermal cell walls, papillae and trichome walls, and microprojections of mesophyll cell walls were Toluidine Blue and zinc chloride-iodine (D'Ambrogio de Argüeso, 1986, pp. 70, 72), Indophenol Blue (Peacock, 1966), Methylene Blue (Johansen, 1940, pp. 200), and Ruthenium Red, as explained above.

Specific stains and methods used to revea! the nature and contents of trichome cells were the preceding (except for zinc chloride-iodine) plus Lugol's Solution, iodine (both according to Johansen, 1940, pp. 183, 189 and D' Ambrogio de Argüeso, 1986, p. 75), Sudan IV in ethylene glycol (Gurr, 1966, p. 313-314), the Per-iodic-Schiff (PAS) method (Gurr, 1966, p. 296--298), and Sudan IV in saturated isopropanol, a technique I developed.

\section{EPIDERMAL PAITERNS AND CELL WALLS}

Cell sizes and wall pattems differ in the epiphyll and hypophyll. Wall pattems seen in cleared preparations are straight, angular, or sinuous (Figs. IL, H, E), and the latter two kinds may be either frequent or subfrequent (e.g., sinuous-frequent, angular-subfrequent). Walls themselves seen in cross-section show different degrees of thickening across the walls and differences in regularity of thickening along the walls.

The epiphyll cells of C. aescul\{folia subsp. aesculifolia (Fig. 1A) are larger and have slightly thinner walls (Fig. IB) than those of the otller taxa (Figs. IE, r:I, .T). The cells are elongate $(1: \mathrm{w}=2-3: 1)$ in C. aesculifolia, but are nearly isodiametric in C. lobbiana. Ali epiphylls have a sinuous-frequent pattem (Figs. 1A, E, I). The sinuosities are slightly more marked in C. lobbiana (Figs. 11, J) than in the other taxa. The wall thickenings are generally more marked in C. aesculifolia subsp.aesculifolia and in C. lobbiana (Figs. IB, J) than in sorne material of C. aesculifolia subsp. korthalsii (Fig. 1F), and the latter subspecies has more irregular thickenings.

The epiphyll pattems of Chrístensenia are noticeably like those of some Danaea species, especially D. nodosa (L.) J. E. Smith, whereas Marattía and other Danaea species have angular epiphylis (Rolleri et al.• 1987).

The hypophylls are more variable than the epiphylls. In C. aesculifolia subsp. aesculifolia, the pattem is sinuous-subfrequent with shallower sinuosities, the cells are somewhat elongate $(1: \mathrm{w}=2-3: 1)$, and the cells are more iffegularly thickened than in the epiphyll (Figs. 1C, D). In C. aesculifolia subsp. korthalsii, the pattem is angular-subfrequent, the cells are more elongate $(1: \mathrm{w}=2-4: 1)$, and the thickened areas of the cells are irregular (Figs. 1G, H). In C. lobbiana, the pattem is polygonal, sorne of the cells are subisodiametric $(1: \mathrm{w}=1-2: 1)$, and the walls are irregularly thickened (Fig. 1 . L).

\section{STOMATA}

The stomata are basically cyclocytic. The guard cells are strongly arcuate and circumscribe the stomatal pare, which may be up to 200-240 i.un in diam. and which may be found in every degree of openness, presumably depending upon ambient climate. The subsidiary cells are arranged in 2-3(5) cycles of narrow, arcuate cells that are distinct from the adjacent epidermal cells. Unlike most stomata, ali the cells in Christensenía, including even the fourth and fifth cycles of subsidiary cells, protrude above the plane of the epidermis. 


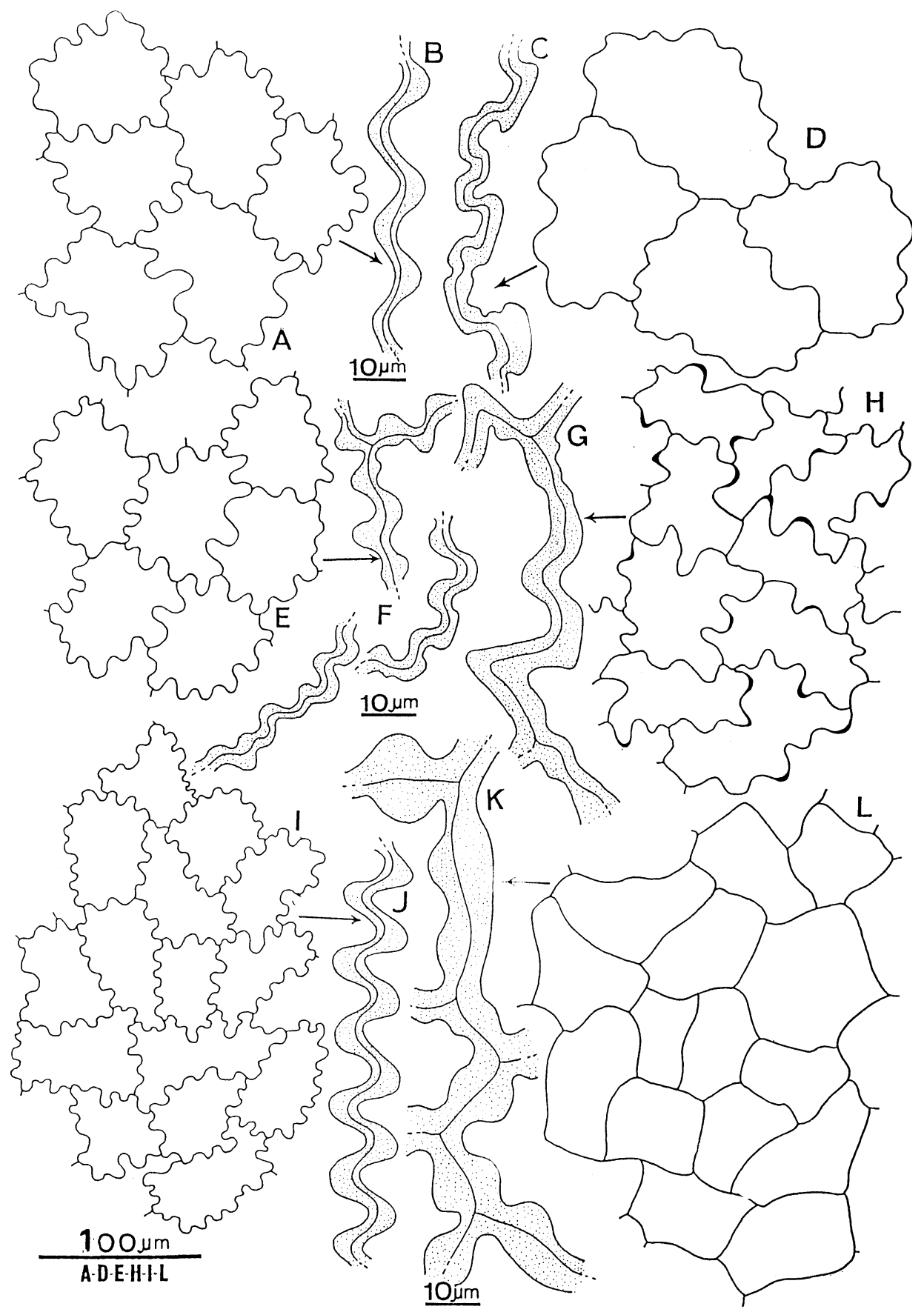

Fig. 1. Epi<lermal patterns an<1 details of cell walls in Christensenia. A-D. C. aesculifolia subsp. aesculifolia. A, B. Epiphyll. C. D. Hypophyll. E-H. C. aesculifolia subsp. korthalsii. E, F. Epiphyll. G, H. Hypophyll. 1-L. C. lobbiana. !, J. Epiphyll. K, L. Hypophyll. 
Rolleri et al. (1991a) studied the ontogeny, development, and physiology of these stomata in C. lobbiana (as cumingiana), which they named porocyclocytic. In this species the ontogeny is perigenous. The typical cyclocytic stomata of other genera of the Marattiales, which also can be seen in apical and marginal areas of Christensenia pinnae, represent a phase toward the fully developed porocyclocytic stomata of Christensenia.

In C. aesculifolia subsp. aesculifolia, the paired guard cells are very large and strongly arcuate; in subsp. korthalsii a third guard cell has rarely been seen; in C. lobbiana, the guard cells occasionally divide anticlinally after the pore is fonned, and up to 5 of them can be found in a single stoma in the pinna apices, intenningled with more typical stomata having a single pair of guard cells.

Rolleri et al. (1991a) interpreted the porocyclocytic stomata as an adaptation to the functions primarily of gas exchange and secondarily of liquid water secretion, as if the stomata were hydathodes. Given the highly humid ambient conditions of Christensenia, the stomata probably act in these ways altemately.

\section{ThICHOMES}

The epiphylls of Christensenia are always glabrous. The hypophyll of C. aesculifolia subsp. aesculifolia is subglabrous (Figs. 2A-E) to glabrous, with a scattering of branched hairs and a few uniseriate hairs. The costae and veins bear a few scales and occasionally smooth papillae. The hypophylls of the other taxa have a random mixture of indument types in the veins and lamina surface, giving them a characteristic trichomatose appearance that is easily seen at low magnifications. The hypophylls of Danaea bear a similar indument (Rolleri et al., 1991b).

The trichomes of Christensenia are ali glandular in nature. Tests for fats were strongly positive for capitate cells and papillae, whereas tests for starch, saponine, essential oils, inuline, and proteins were negative. In contrast, the trichomes of Danaea are tanniferous. Trichome walls are cellulosic with weak traces of a cutio layer. Although four kinds of trichomes can be distinguished, intermediate stages between papillae and unbranched hairs, between unbranched and branched hairs, and between branched hairs and scales are known, and ali probably share a common ontogenetic ancestor. This is confinned by microchemical assays, which tend to show that ali trichomes of the hypophyll are of the same origin.

Globose papillae. -Protruding, dome-shaped, reddish-brown papillae with a smooth or irregular surface (Figs. 3A, Y, A', F', 4A-B).

Uniseriate hairs. -Straight or curved, with a cylindrical or subconical basal cell, 1 to 7 cylindrical body cells that can be shorter than the basal cell, and a capitate apical cell (Figs. 2F-J, A'-C, 3B-E, I-N, B'-F').

Branched hairs. -Straight or rarely curved, with a cylindrical or subconical basal cell, a paucicellular body prolonged into short, paucicellular or uniserjate processes, and a capitate cell at the apex of each process. These trichomes are very diverse (Figs. 2A-E, S-Y, D', 3F-G, P-U). Sorne appear to be transitional between uniseriate hairs and branched hairs (Figs. 2K, 30).

Sea/es. -Pluricellular, with a cylindrical basal cell, a partially to totally flattened body, with very short, paucicellular or unicellular processes, and a capitate cell at the apex of each process (Figs. 2Z, E', 3H, V-X, G'). Sorne appear to be transitional between branched hairs and scales (Figs. 2L-R, 3P-T). Despite lheir ftattened bodies, these scales are not coordinate with the scales that are typical of the higher fems, which appear to dif- 


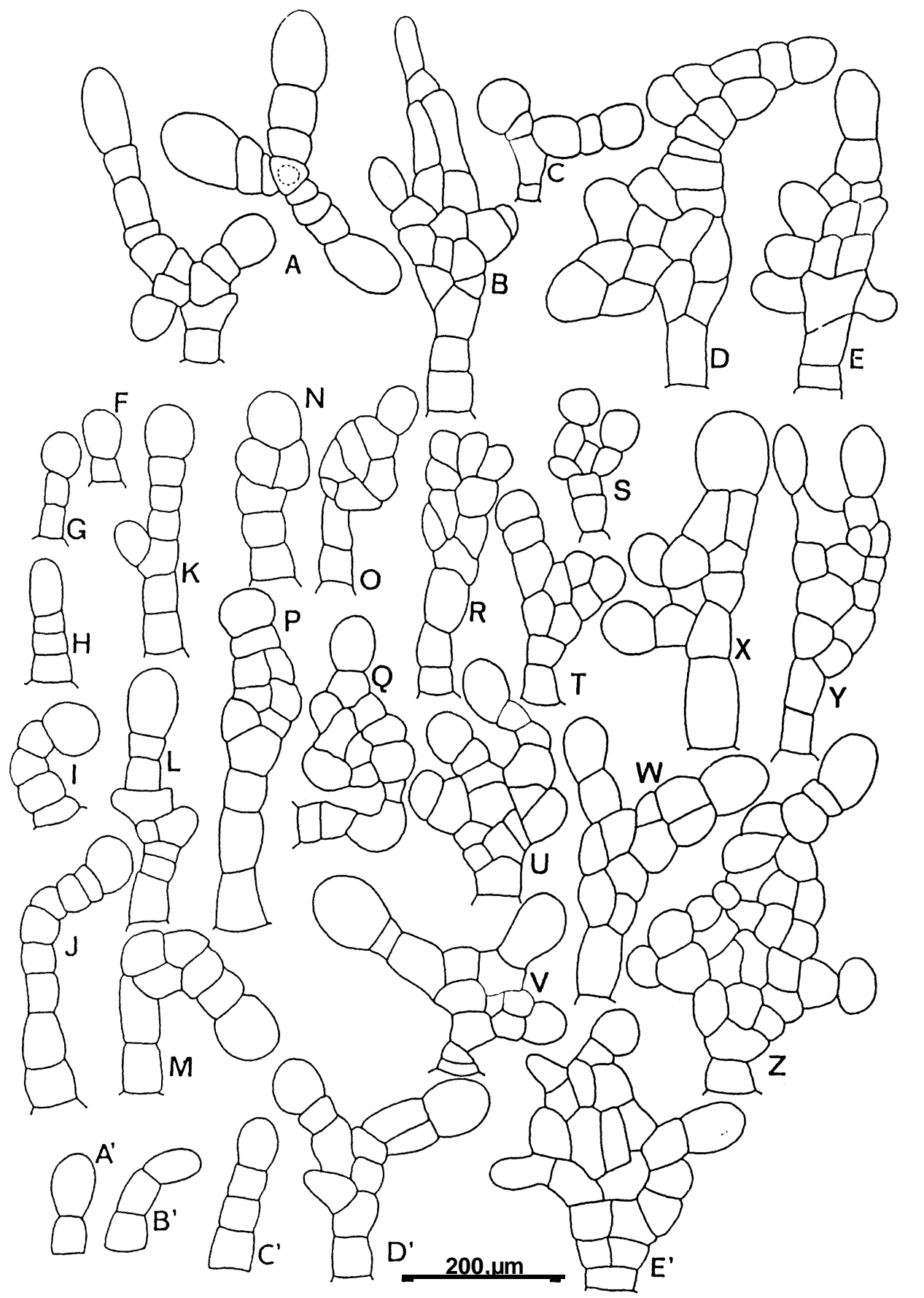

Fig. 2. Trichomes of the Janúna surface in Christensenia. A-E. C. aesculifolia subsp. aesculifolia. F-Z. C.aesculifolia subsp. korthalsii and C. lobbiana types in common. A'-E'. Additional types in C.lobbiana (superficial papillae not shown). 


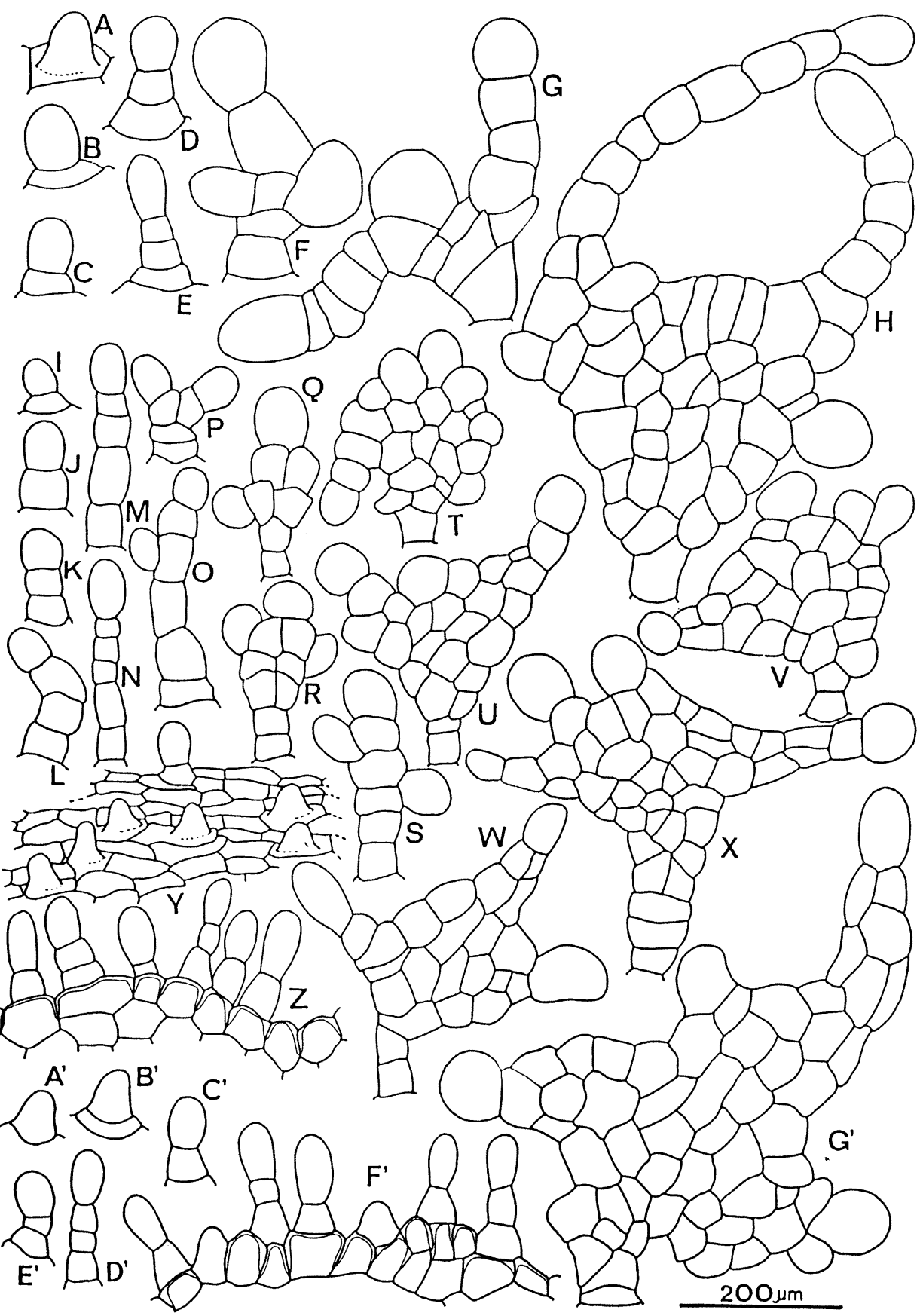

Fig. 3. Trichomes of the veins in Christensenia. A-H. C. aesculifolia subsp. aesculifolia. Z. C. aesculifolia surap. korthalsii. A:-G' . C. lobbiana. Y. Secondary vein as seen in surface in C. aesculifolia subsp. korthalsii. Z. Same in cross-section. F'. Cross-section of vein. H, X, and G. Scales. 

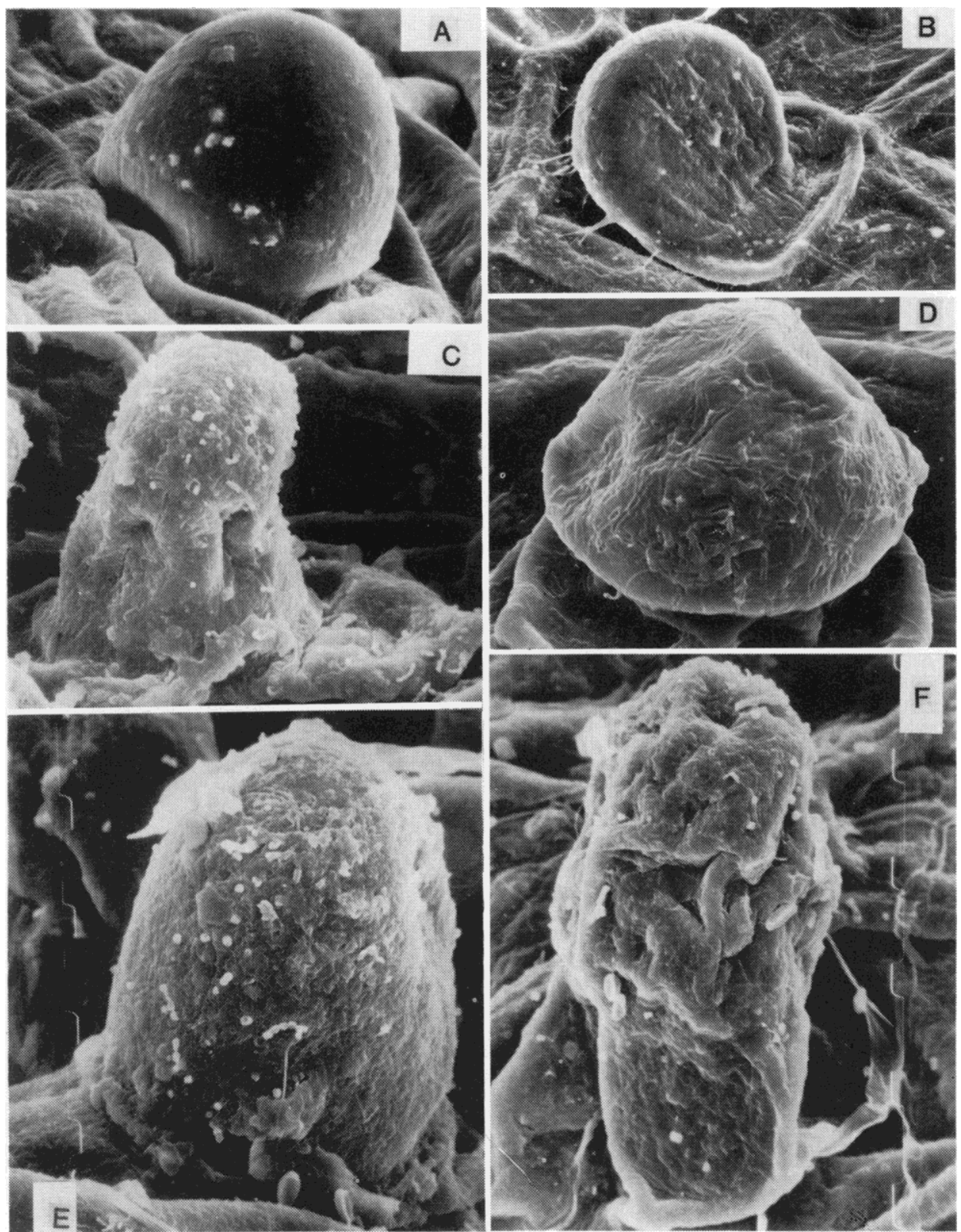

Fig. 4. SEM photographs of trichomes in Christensenia. A. Smooth papilla on secondary veins of C. aesculifolia subsp. konhalsii (abundan! and dense). B. Small, superficial papilla in C. lobbiana. C-D. Bicellular lrichomes in C.aesculifolia subsp. konhalsii. E. Large, rugose papilla on lamina and near veins in C. lobbiana. F. Bicellular lrichome in C.lobbiana. Magnifications: A-B, x1500; C-F, x2000. 
fer more markedly from hairs. Although they are the final developmental phase of trichomes in Christensenia, they appear to be an expansion of branched hairs.

\section{MICROPROJECTIONS OF MESOPHYLL CELL WALLS}

The laminae of Christensenia lack a typical photosynthetic palisade layer. The mesophyll cel!s are uniform, Y-branched, and connected by their ends, leaving wide intercellular spaces. They can be seen clearly through the ample stomatal pores and their most outstanding characteristics, the rod- or club-shaped microprojections of their outer walls (Figs. 5, 6). Luerssen (1873) illustrated them for C.aesculifolia sensu lato (as Kaulfussia) and also noted their appearance in roots, rhizomes, and stipes of Angiopteris (Luerssen, 1875). He thought the microprojections were composed of cellulose and cutin. Bary (1884) described them as projections of the cellular walls. Gardiner (1885) described them as composed of mucilage in Aspidiumfilix-mas, Blechnum brasiliense, and other fems. Schenk (1886) stated that their composition does not include cellulose or waves and that their biological meaning was enigmatic. Campbell (1911, p. 204) described them as "mainly composed of calcium pectate." Pettit (in Hill and Camus, 1986) suggested that they do not contain either proteins or lipids and that tests point to the presence of polysaccharides.

The microchemical tests 1 carried out indicated a general presence of hydroxylate polysaccharides (predominately cellulose) and traces of pectinate mucilages in the rounded ends of the microprojections and also in their lateral walls (mixed with cellulose).

The microprojections vary in density and relative size. The longest and narrowest microprojections are found in C. aesculifolia subsp. aesculifolia, especially from the Solomon Islands (Figs. 5D-E); the shortest, sometimes verrucose and with rounded ends, are found in C. aesculifolia subsp. korthalsii (Figs. 6D). The microprojections of C.lobbiana are similar to those of $C$. aesculifolia, but are more densely distributed (Figs. 6E-I). Variability may be related to habitat, rather than being taxonomically diagnostic. One could hypothesize that the presence of microprojections is related to the efficiency of water movement and retention within the pinnae. The mesophyll is poorly developed, only a few layers thick, and so the movement of water and water vapor within it would be strongly facilitated by the large stomatal pores. The microprojections on the outer walls of mesophyll cells would enlarge their hygroscopic surface, insuring a constant and dynamic water balance. The mucilaginous tips of the microprojections suggests this hygroscopic function.

\section{SYNANGIAL RECEPTACLES AND PARAPHYSES}

The synangia of Christensenia are elevated above the lamina surface by parenchymatous receptacles that appear dome-shaped in cross-section. The parenchyma on which the synangium lies is sclerosed, and the cells are lignified (microchemical tests indicate a high concentration of polyphenols in the cell walls). When the synangium is shed, the circular or elliptical scar formed by the dark brown, sclerosed cells is easily visible. Hill and Camus (1986) did not study the receptacles in detail and used the term placenta for them. However, that term has angiospermic connotations and need not be used in preference to the term receptacle.

Paraphyses are borne on the perimeter of the receptacles. Although paraphyses stain intensely with Ruthenium Red, they are eglandular and their cell walls are very thin and 

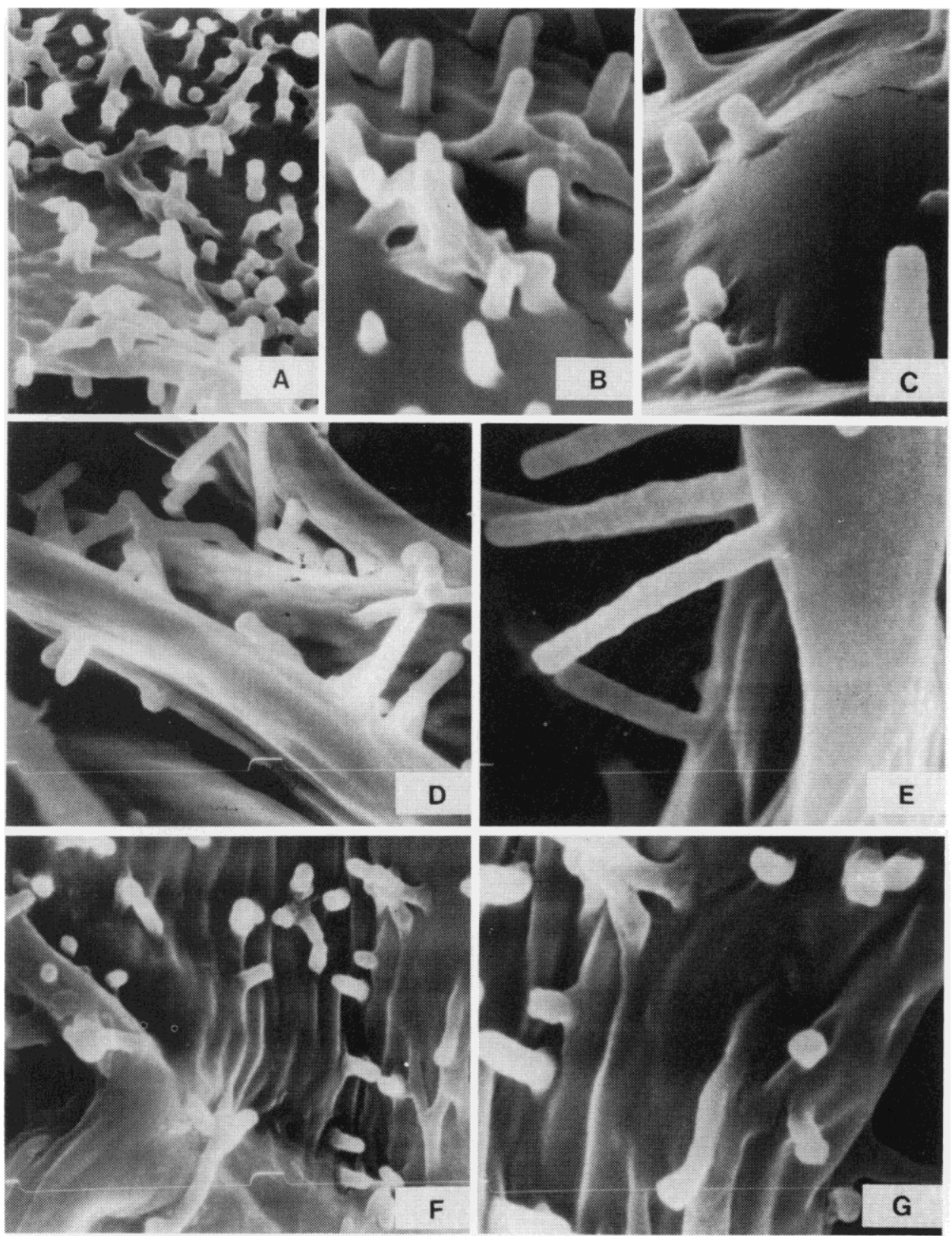

Fig. 5. Microprojections of mesophyll cell walls in Christe11Se11ia aesculifolia subsp. aesculifolia. A-C.. From Java (Zol/ill ger 1902, P). D-E. From the Solomon Islands (Braithwaite 4220, P). F-G. From Java (Buysman 2607, P). Magnifications: A, D. F, X5000; B, C, E, G, XIOOOO. 


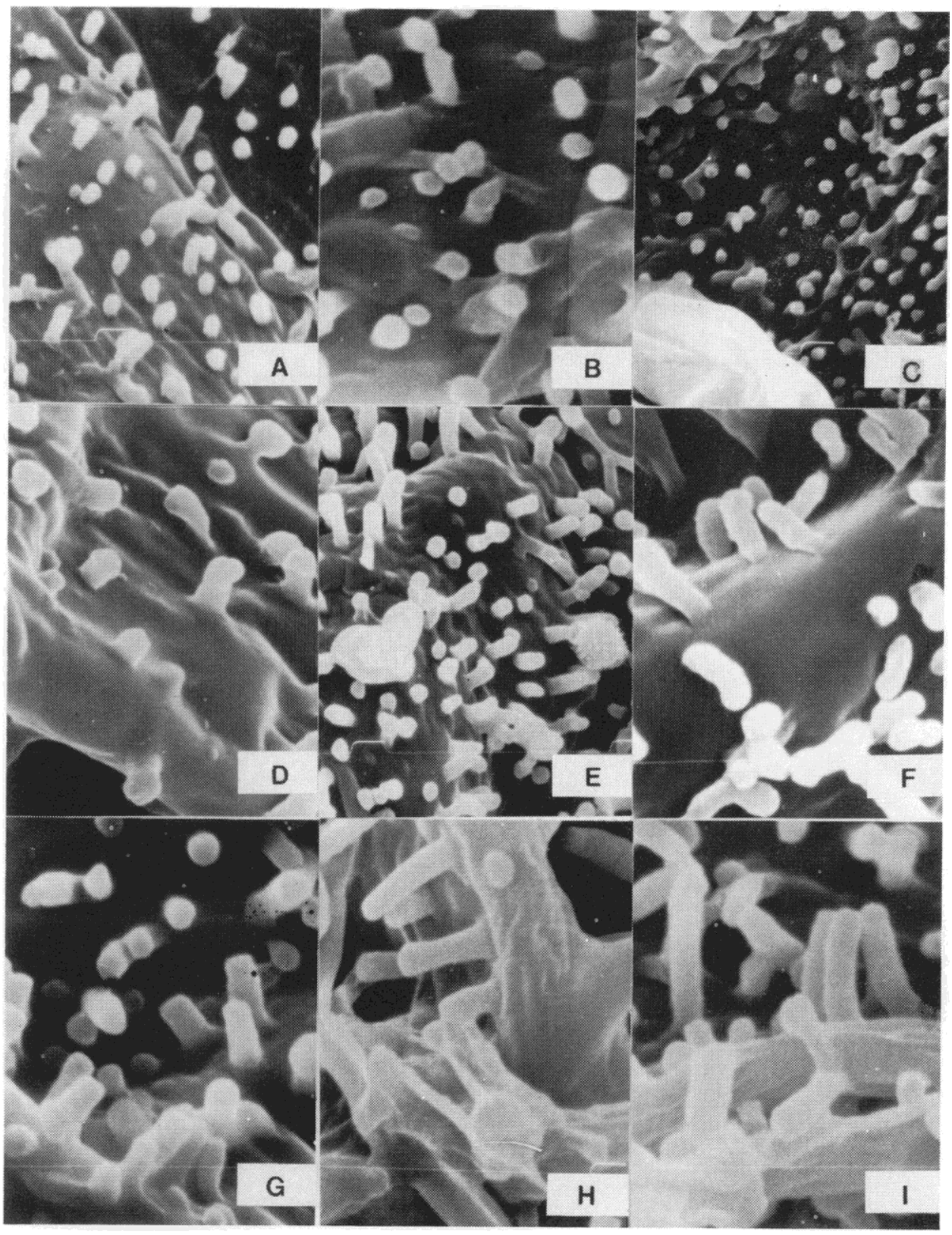

Fig. 6. Miaoprojections of rnesophyll cell walls in Christensenia. A-8. C. aesculifolia subsp. korthalsii frorn Surnatra (Brooks 70S, P). C-D. Sarne, frorn the Philippines (Cope/and 2063, P). E--1. C. lobbiana from the Philippines. \&-F. Copeland s.n. (P). G-H. \&laño 36839 (P). 1. Robinson 17914 (P). Magnifications : A, C, E, XSOOO. B, D, F-1,XIOOOO. 


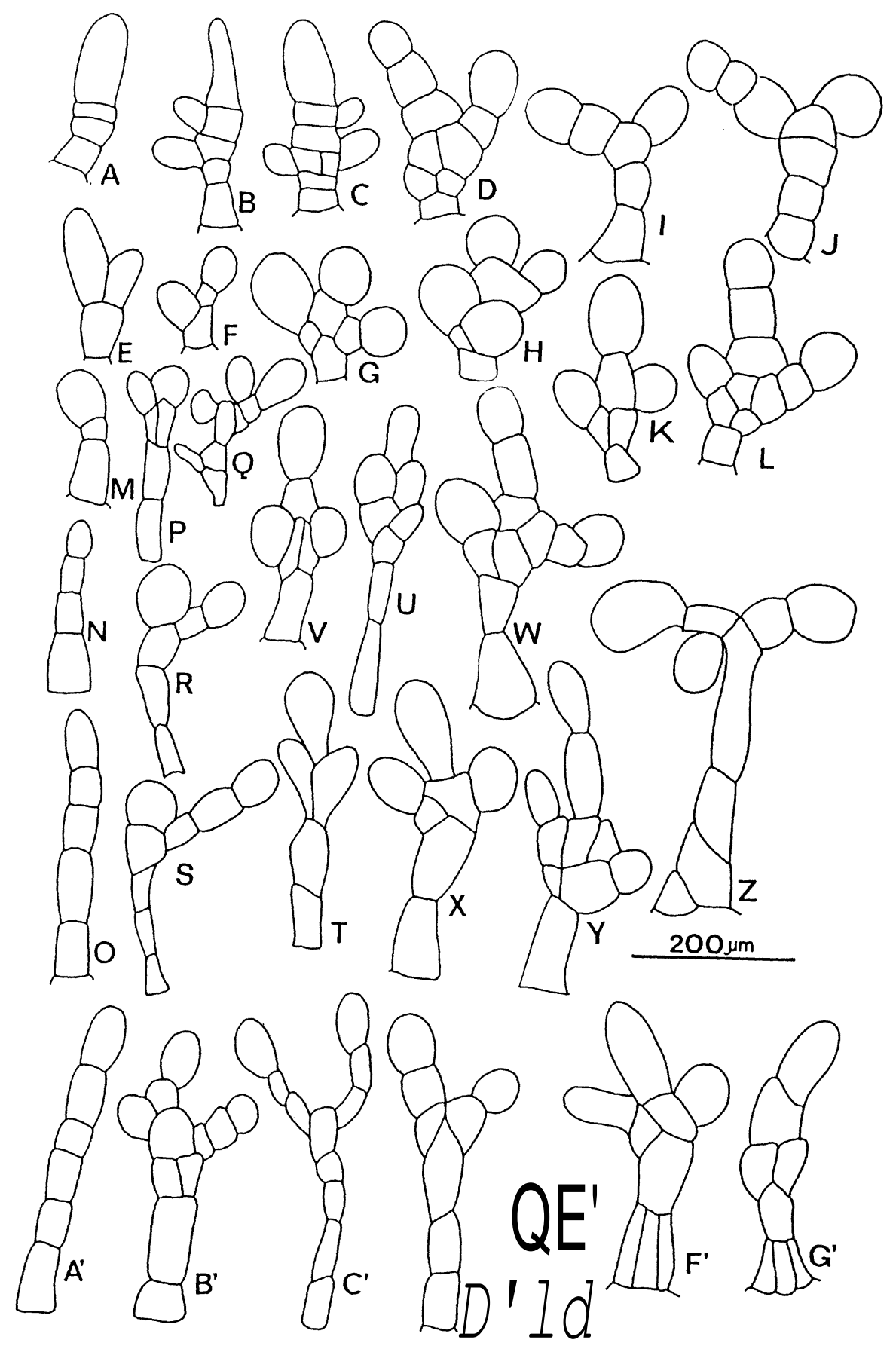

Fig. 7. Paraphyses in Christensenia. A-J. C. aesculifolia subsp. aesculifolia. K-Z. C. aesculifolia subsp. korthalsii. A'-G'. C. lobbialla. 
cellulosic. Sorne of tbe hair-like paraphyses differ in shape and density in tbe taxa. Most paraphyses are uniseriate (Figs. 7A, M-0, A'), but a few are Y-shaped (Figs. 71-J, Z, $\mathrm{C}^{\prime}-\mathrm{D}^{\prime}$ ). In C. /obbiana, paraphyses with a 3-celled base were seen (Figs. 7F'-G'). A few paraphyses resemble variously branched hairs (Figs. 7W-Y). Paraphyses having tbe fonn of small triangular, caducous scales have been observed occasionally at tbe edge of receptacles of young synangia of all taxa. These are of no taxonomic significance. Hill and Camus' (1986) term placental hair need not supplant tbe more usual tenn paraphysis.

\section{TAXONOMIC ThEATMENT}

Christensenia Maxon, Proc. Biol. Soc. Wash. 18:239. 1905. -TYPE: A renaming of Kaulfussia Blume, and so based on tbe type of that name.

Kaulfussia Blume, Enum. Pl. Javae 2:260. 1828, nec Dennst. Schlüssel Hortus Malab. 30. 1818, nec Nees Horae Phys. Berol. 53, f. 11. 1820. -TYPE: Aspidium aesculifolium Blume [= Kaulfussia aesculifolia (Blume) Blume].

Macrostoma Griff. Asiat. Res. 19:108. 1836, non Hedwig, Gen. PI. 102. 1806, which is Macrostema Pers. Syn. Pl. 1:185. 1805.

Plants terrestrial, at 1-1000 m elevation, usually in very dark shade in undisturbed forests on banks of small streams or rivers or on humid slopes. Rhizomes short-creeping, subascending, or erect, carnose to subcamose, scaly, tbe scales basifixed, wide and rounded witb undulate margins, castaneous witb reddish spots. Stipes 1 or more, $8-35(45) \mathrm{cm}$ long, stiff, carnose, slightly to deeply canaliculate, papillose and with scattered trichomes, tbe papillae very dense, bright reddish-brown, the trichomes similar to tbose of tbe costae. Fronds simple, ternate, or palmate with five pinnae. Laminae lanceolate or broadly so in simple fronds, nearly symmetrical to irregular, usuaily with a shallowly cordate or irregularly rounded base, tbis sometimes widened and undulate, witb an acute, acuminate, or rarely obtuse-cuspidate apex. Pinnae of compound fronds sessile or nearly so, in ternate laminae the tenninal one generally symmetrical, witb a cuneate base and an acute or acmninate apex, the lateral pair pedate, sometimes quite reduced, in palmate laminae tbe terminal pinna similar, tbe basal pair strongly pedate or reduced or even curved. Laminae herbaceous, spongy, subcoriaceous, coriaceous, or camose, the epiphyll smootb, bright dark green, the hypophyll opaque, light green to pale yellow. Costae and primary veins abaxially rigid and prominulous, roughly striate, indurated, and subglabrous, or slightly prominulous, not indurated, and distinctively papillose-trichomatose. Secondary veins anastomosing to form a reticulum of polygonal areolae with free included veinlets. Trichomes, if present, all glandular, a mixture of papillae, uniseriate hairs, branched hairs with a paucicellular body, and more elaborated scales witb a pluricellular body and uniseriate processes, all with thin, cellulosic, slightly cutinized walls. Synangia circular to elliptic, tbe fused sporangia 8-12. Receptacles prominulous, mostly parenchymatous, but witb the surface cells sclerosed. Paraphyses bordering tbe receptacles uniseriate and pluricellular or more commonly similar to the branched hairs of tbe lamina, but witb more delicate, tbinner walls and lacking glandular apical cells. Spores monolete, elliptic in polar view, witb a conical/spinulose ornamentation of close, short, sharp, but soft, spine-like processes throughout.

Distribution: India, Burma, Malaya, Sumatra, Java, Borneo, tbe Philippines, and the Bismark and Solomon lslands (Fig. 8). 


\section{KEY TO CHRISTENSENIA}

1. Plants small to medium (up to $35 \mathrm{~cm}$ long); stipes densely papillose, often carnose, (9)10-23(25) cmlong; fronds simple, occasionally temate, rarely palmate, tbe lamina (or terminal pinna in compound fronds) lanceolate to broadly so, 9-10(15) cm long, 3-4(9) $\mathrm{cm}$ wide; lateral basal pinnae, if any, reduced in ternate fronds, pedate in palmate ones; laminae herbaceous to spongiose, often subcamose; veins and lamina surface papillosetrichomatose, tbe trichomes diverse, bright, reddish-brown tbroughout. Laminae green adaxially, yellowish-green abaxially 3. C. lobbiana

I. Plants medium to large (30-80 cm long); stipes (6)18-36(50) cm long, not densely papillose, stiff, deeply canaliculate in large fronds; fronds palmate, occasionally temate, rarely simple, tbe terminal pinna (or lamina in simple fronds) lanceolate to rhomboidal, $15-18(25) \mathrm{cm}$ long, 7-9(15) cm wide; lateral suprabasal pinnae, if any, asymmetric to pedate; lateral basal pinnae, if any, pedate; laminae herbaceous, papyraceous, subcoriaceous, or coriaceous; veins and lamina surface papillose-trichomatose, subglabrous, or glabrous, tbe trichomes, if any, diverse or reduced, yellowish except for the reddishbrown glandular cells

2. Indument diverse, tbe costae, veins, and lamina surface mostly papillose-trichomatose, tbe last abundantly so, tbe trichomes reddish-brown to reddish, mixed witb dense papillae; laminae herbaceous to papyraceous, dark green adaxially, pale green abaxially.....

\section{C. aesculifolia subsp. korthalsü}

2. Indument reduced toabsent, tbe veins witb scattered scales and occasional papillae not visible to tbe naked eye, tbe lamina surface witb a few trichomes but no papillae; laminae subcoriaceous to coriaceous, green adaxially, pale green abaxially (or slightly yellowish in specimens from tbe Bismarck Archipelago and the Solomon Islands

1. C. aesculifolia subsp. aesculifolia

I. Christensenia aesculifolia (Blume) Maxon, Proc. Biol. Soc. Wash. 18:240. 1905, subsp. aesculifolia. -Aspidium aescullfolium Blume, Enum. Pl. Javae 2:143. 1828. -Kaulfussia aesculifolia (Blume) Blume, Enum. Pl. Javae 2:260. 1828. -TYPE: Java, "crescit in Javae Provinciae Bantam," Blume (holotype L not seen Morton photo 766US; isotype P? not seen).

Plants terrestrial, robust, up to $70(80) \mathrm{cm}$ long; rhizomes erect to suberect, short, carnose, scaly, the scales large, rounded, undulate to subentire, bicolorous, castaneous witb reddish spots; stipes fteshy when young, stiff and canaliculate at maturity, subpapillose and witb scattered, small, castaneous-reddish scales; fronds palmate or occasionally temate, tbe terminal pinna rhomboidal to broadly lanceolate, up to $22-25 \mathrm{~cm}$ long, $11-15$ $\mathrm{cm}$ wide, cuneate at the base, acute to acuminate at the apex, tbe distal pinnae, if any, asymmetrical, the proximal pinnae pedate to almost crescent-shaped; laminae papyraceous to coriaceous, tbeir margins entire or slightly undulate, revolute, subpapillose; costae prominent, rigid, indurated, glabrous to subglabrous, with scattered, variously branched hairs and scales; primary veins prominulous and rigid; lamina surface glabrous to subglabrous, sometimes witb scattered, variously branched hairs, papillae absent; synangia usually circular, tbe fused sporangia 8-10; receptacles circular to elliptical; 


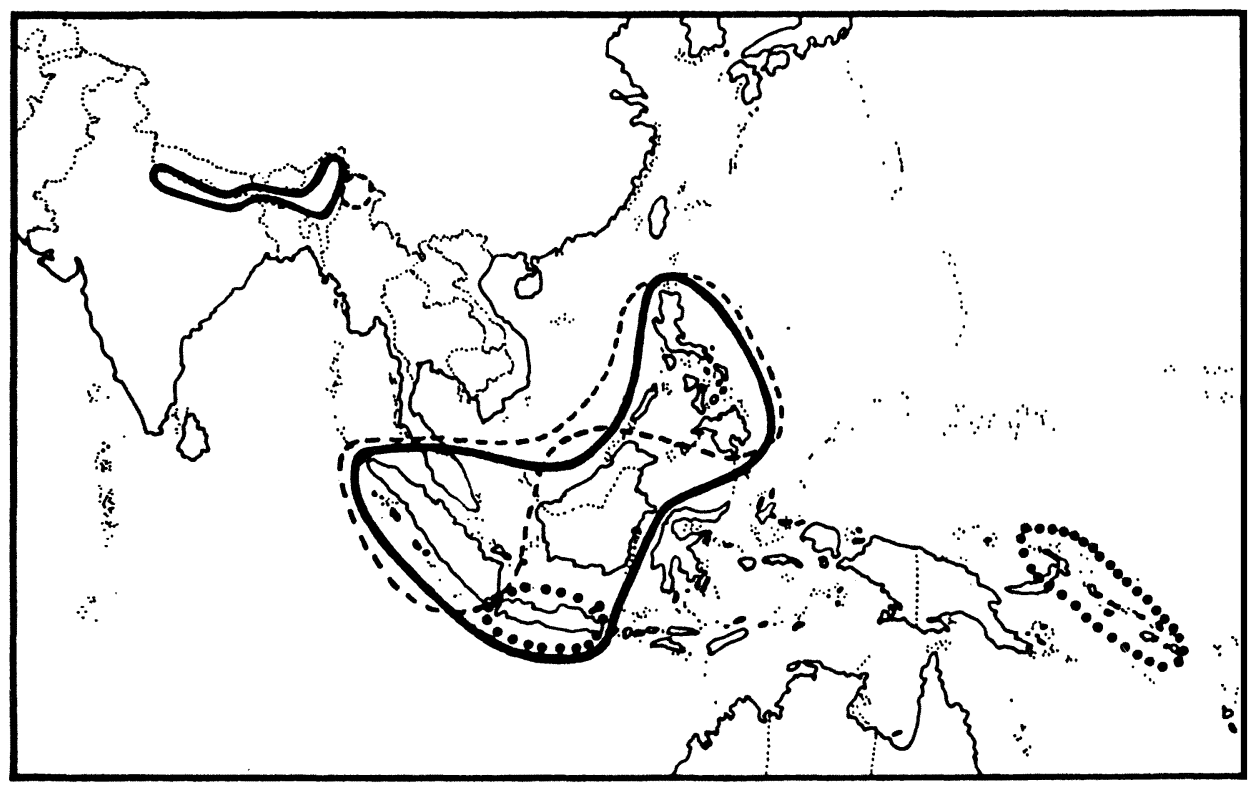

Fig. 8. Geographical distribution of the laxa of Christensenia. Solid line = C. aesculifolia subsp. aesculifolia . Dotted line $=$ C. aesculifolia subsp. korthalsii. Dashed line $=$ C. lobbiana .

paraphyses commonly short, paucicellular, simple, forked, or branched; scales small, caducous.

Cytology. - Previous cytological studies recorded $2 n=80$ for plants from Borneo (Walker, 1979) and $2 n=160$ for plants from the Solomon lslands (Braithwaite, 1977). Both numbers are based on $x=40$, also known for other genera of Marattiales. Although the Solomon lsland plants are tetraploid, they show no essential morphological differences from other, presumably diploid, specimens of this subspecies. At present, it seems best to include the tetraploids in subsp. aesculifolia pending further study, especially of the nature and origin of their tetraploid condition.

Specimens examined: JAVA: Salak, Raciborski s.n. (US); Batavi, Perbati, W slope of Mt. Salak, Palmer \& Bryant 670 (US); Basamala, Raciborski s.n. (P); Indat [?] Mountain, Forbes 550 (US); near Bogor, Buysman 2607 (P); without specific locality, 'Zollinger 1902 (P). BISMARCK ARCHIPELAGO: New lreland: Namatanai, Mandiu Lake 6 km WNW of Taron, Croft (LAE) 68399 (US). SOLOMON ISLANDS: E. San Cristóbal, lower reaches of Sumaro River, Braithwaite 4215 (BM, P); E. San Cristóbal, just below conftuence of Warahito and Pagato rivers, Braithwaite 4220 (BM, P).

2. Christensenia aesculifolia subsp. korthalsii (deVriese) Rolleri, comb. nov. Kaulfussia korthalsii de Vtiese, Ned. Kruidk. Arch. 1(3):186. 1852.-TYPE: Sumatra, Korthals s.n. (holotype L not seen Morton photo 767 US).

Kaulfussia assamica Griff. Asiat. Res. 19:108. 1856. -- Christensenia assamica (Griff.) Ching, Fl. Reipub. Pop. Sínica 2:65. 1959. — TYPE: "Assam," Grijfith 1696 (holotype BM not seen photocopy BM; isotype P). 
Plants terrestrial, flexible, delicate, up to 40-45 cm long; rhizomes short, carnose, scaly, the scales adherent, large, castaneous with reddish spots, the margins entire to undulate; stipes subcamose in smaller plants (juveniles?) to somewhat rigid, stiff and striate in the largest plants, scaly, the scales scattered, small, peltate, castaenous to reddish brown; fronds temate, occasionally palmate, rarely simple, the terminal pinna (or lamina in simple fronds) lanceolate to narrowly so, $15-18 \mathrm{~cm}$ long, $7-9 \mathrm{~cm}$ wide, slightly ascending and curved; laminae herbaceous, rarely papyraceous, with plane or slightly revolute margins, these subpapillose, usually undulate, serrate, or serrate-denticulate, rarely entire; costae and veins papillose-trichomatose, densely covered with papillae, the hairs and scales diverse; synangia commonly circular, the sporangia 8-12; receptacles circular; paraphyses similar to branched trichomes, but eglandular and more delicate.

Specimens examined: INDIA: Assam, Margherita, Lakhimpur District, Mann s.n. (US); "Assam, Ind. angl.," Griffith s.n. (P, possible isotype of K. assamica ); Assam, Makumi Forest, Lakhimpur, Mann s.n. (P). MALAYA: Selangor, Molesworth-Allen 2439 (US); Perak, Larut, King 4784 (P); Perak, Scortechini s.n (P); Perak, Batang Padang, Ridley 13927, 13928 (P); without locality, Ridley 14244 (P). SUMATRA: Lebong Tandai, Benkoelen, Brooks 70.S (P, US), 113.S (P); without locality, Hancock 29(US); Sarawak, near Kuching, above 'Rajah' bungalow 3/4 of the way to Mt. Matang, Molesworth-Allen 8146 (US); Central Kalimantan, Bukit Raya and upper Samba River 60-80 km NNW of Tumbang Samba, base camp Tumbang Riang, M ogea 3637 (US). PHILIPPINES: Mindanao, Davao, Todaya, Mt. Apo, Elmer 11275 (P, US); Negros, Luzon, Copeland 2063 (P, US); Camarines, Mt. Isarong, Ramos 7513 (P, US); Mt. Maquiling, Copeland s.n. (P); Luzon, Rizal, Panintingan, Loher 13568 (P).

3. Christensenia lobbiana (de Vriese) Rolleri, comb. nov. - Kaulfussia lobbiana de Vriese in de Vriese and Harting, Monogr. Marattiac. 14. 1853. -TYPE: "Habitat in insulam Javam," Lobb (K-Hb. Hook. not seen). [Note the polygonal epidermal pattem of the hypophyll illustrated in figs. 5A-D.]

Christensenia cumingiana Christ, Philippine J. Sci., Bot. 2:186. 1907 - TYPE: Philippines, Mindanao, Prov. Zamboanga, Copeland s.n. (MICH not seen; possible isotype US).

Plants terrestrial, generally small, (18)20-30(32) cm long; rhizomes suberect to shortcreeping, short, bearing several stipes, scaly, the scales large, round, adherent, castaneous with reddish spots, with undulate or entire margins; stipes camose, often slightly striate, not rigid or canaliculate, pale yellow with red spots, papillose; fronds simple or rarely ternate; simple laminae and terminal pinnae of temate laminae lanceolate; lateral pinnae asymmetrical, pedate, sometimes reduced, sessile, lanceolate to triangular, roundedlobate, rounded-undulate, and very irregular (small pinnae occasionally asymmetrically cuneate) at the base, the margins undulate, se Trate, or lobate, the laminae usually spongiose; reddish to castaneous-reddish, glandular papillae, hairs, and scales of ali types present on the costae, veins, and lamina surface, contrasting with the pale yellow hypophyll; synangia frequently elliptic, with 9-12 fused sporangia; receptacles elliptic or circular; paraphyses abundant, similar to branched trichomes, but delicate and eglandular.

Specimens examined: BURMA: Warzup [Warazup], Sidney 2 (US). MALAYA: Kepong, Sungei Kerod, near Kuala Lumpur, Selangor, Molesworth-Allen 24344 (US). 
SUMATRA: Indragiri, "in silvis prope pi. Lalh.," Burchard 46 (P). PHILIPPINES: Mindanao, Prov. Zamboanga, San Ramón, Copeland 152 (US, possible isotype of $C$. cumingiana), Copeland s.n. (P, possible isotype of C. cumingiana ); Mindanao, Zamboanga, Edaño 36838, 36839 (both P, US); Capiz, Panay, Ramos \& Edaño 31199 (US); Luzon, Mt Maquiling, Robinson 17914(P, US), Robinson 17199(US); Sorsogon, Mt. Bulusan, Elmer 15915(P, US).

\section{ACKNOWLEDGMENTS}

This research was carried out through a grant from the Consejo de Investigaciones Científicas y Técnicas (CONICET) of Argentina, and was completed at the Department of Botany, Smithsonian Institution, Washington, OC, where the autllor had the support of a Short Term Visitor's Grant. Thanks are due to David Leilinger for numerous suggestions, advice in matters of taxonomy and nomenclature, and reading of the manuscript. Amelía Deferari and María del Carmen Lavalle gave valuable comments on morphology and physiology. Vuginia Duarbier de Natoli (CONICET) made lhe drawings.

\section{LITERATIJRE CITED}

BAJCER, J. G. 1874.Synopsis Filicum, ed.2. RobertHardwicke, London.

BARY, A. DE. 1884. Comparative Anatomy of the Vegetative Organs of the Phanerogams and Ferns. Clarendon, Oxford.

BRArrHWAITE, A. F. 1977. A chromosome count and range extension for Christensenia (Marattiaceae). Amer. Fern J. 67:49-50.

CAMPBELL, D. H. 1911. The Eusporangiatae: The Comparative Morphology of the Ophioglossaceae and Marattiaceae. Carnegie Inst. Wash. Pub!. 140:i-vi, 1-229, t. 1-13.

CAMUS, J. 1990. Marattiaceae in Kramer, K. U. \& P.S. Green, eds. TI1e Families and Genera of Vascular Plants, 1.Pteridophytes and Gymnosperms. Springer Verlag, Berlín.

OnNG, R. C. 1940. Christenseniaceae, a new fern family in tropical Asia. Bull. Fan Mem. Inst. Biol., Bot. 10:227-229.

. 1959. Pteridophyta: Ophioglossaceae-Oleandraceae. Aorae Reipublicae Popularis Sinicae, vol. 2. Academy of Science, Beijing.

CHRisr, H. 1907. Spiciligium Filicum Philippinensium novarorum aut imperfecte cognitarum. Philippine J. Sci. IIC, Bot. 2:186-187.

Onusti!nSEN, C. 1938. Filicineae in F. Verdoorn, ed. Manual of Pteridology. Martinius Nijhoff, The Bague.

COPEl.AND, E. B. 1909. The ferns of the Malay-Asiatic region, 1. Philippine J. Sci. IIC, Bot. 4:8-11.

. 1958. Fern Aora of the Philippines, Vol. I.Bureau of Printing, Manila.

DAMBrogio De ARGOESO, A. 1986. Manual de Técnicas en Histología Vegetal. Hemisferio Sur, Buenos Aires.

FOSTER, A. 1934. The use of tannic acid and iron chloride for staining cell walls in meristemalic tissues. Stain Technol. 9:91-92.

GARDINB, W. 1885.TI1e continuity of protoplasm in plant tissues. Nature (London) 31:391.

GURR, E. 1966. The Rational Use of Oyes in Biology. Williamson and Wilkers, Baltimore. (Also published by Arrowsmitl1, Bristol. England and Leonard Hill, London, London, 1965.)

HD..L, C. R. \& J. CAMUS. 1986. Evolutionary cladistics in Marattialean ferns. Bull. Bril. Mus. (Nat. Hist.), Bot. 14(4):219--294.

HoLTrUM, E. E. 1955. A Revised Aora of Malaya, vol. JI. Ferns of Malaya. Governmenl Printing Office, Singapore.

JOHANSEN, D. A. 1940.Plant Microtechnique. McGraw-Hill, New York.

luERssEN, C. 1873. Kleinere Miuheilungen über dein Bau and die Entwickelung der Gefásskryptogamen. I. Über die Spaltoffnung von Kaulfussia BI. Bol. Zeit. (Berlín) 31:625-628.

1875. Über Intercellularverdickungen im parenchymatischen Grundgewebe der Faroe. Bol. Zeit. (Berlin) 33:704-705, 718-725.

MAXON, W. R.. 1905. A new name for Kaulfussia Blume, a genus of Marattiaceous ferns. Proc. Biol. Soc. Wash. 18239--240.

Pl!ACOCK, H. A. 1966. Elementary Microtechnique. Edward Arnold, London,

PICHI SERMOLLI, R. E. G. 1970. A provisional catalogue of tlle family names of living pteridophytes. Webbia 25:219-297. 
RoLLERI, C., A. M. DEFERRARI, \& M. ClcIARELLI. 1987. Epidermis y estomatogénesis en Marattiaceae (Marattiales-Eusporangiopsida). Revista Mus. LaPlata, n.s., Bot. 14:124-147.

-, A. M. DEFERRARI \& M. LAvALLE. 199la. Epidernús y estomas porociclocíticos en Christensenia cumingiana Christ (Marattiales). Revista Mus. La Plata, n.s., Bol. 14:149-166.

,A. M. DEFERRARI \& M. LAVALLE. 1991b. Epidermal morphology of pinnae of Angiopteris, Danaea and Marattia. Amer. Fern J. 81:44--62.

SrnENK, H. 1886. Ueber die Stabchen in der Parenchymintercellularen der Marattiaceen. Ber. Deutsch. Bol. Ges. 4:86-92.

VENNING, F. D. 1954. Manual of Advanced Plant Microtechnique. Wm. C. Brown, Dubuque, lowa. VRIFSE, W. H. DE \& P.HARTING. 1853. Monographie des Marattiacées. Arnz, Leide[n) \& Düsseldorf.

WALKER, T.G. 1979. A further chromosome count for Christel1 senia (Marattiales). Fern Gaz. 12:51-52. 